\title{
Impact of Climate Change on Major Marine Industries
}

\author{
Hao Kong ${ }^{1}$, Wei Yang ${ }^{2}$, a , Ping Zhang ${ }^{3}$ and Ricai Peng ${ }^{1}$ \\ ${ }^{1}$ Fujian Provincial Key Laboratory of Coast and Island Management Technology, Fujian Institute of Oceanography, Xiamen 361013, P.R. \\ China; \\ ${ }^{2}$ Third Institute of Oceanography, State Oceanic Administration, Xiamen 361005, P.R. China; \\ ${ }^{3}$ China Institute of Marine Affairs, Beijing 100161, P.R. China
}

\begin{abstract}
Marine economic activities are mainly distributed in areas with extremely fragile ecological environment, rising sea level, rising sea surface temperature, ocean acidification and extreme weather events, etc. These activities have major impacts on the environment and ecosystems of fragile marine and coastal areas, posing a major threat to sustainable development of marine economy. This paper reviews recent researches on the impact of climate change on various marine industries. The results show that climate change has remarkable impacts on marine economy, and some marine industries are especially sensitive. There are both negative and positive consequences of climate change, but no doubt, the negative effects dominate. The government should take pertinent measures to mitigate the adverse effects of climate change.
\end{abstract}

\section{Introduction}

Climate change is an indisputable fact. Over the past 100 years, especially in the past 2 to 3 decades, earth's climate is significantly warming up. The Fifth IPCC Assessment Report ${ }^{[1]}$ further confirmed the significant impact of climate change on the socio-economic system, natural ecosystem, and human survival and development. Studies have shown that climate change has led to frequent occurrences of extreme weather events, threats or even causes irreversible damage to the ecosystem, and results in global economic and social losses.

Due to the special geographical environment and high level human activities in the coastal zone, the ecological environments are extremely fragile in the context of climate change ${ }^{[2]}$.

Rising sea level and surface temperature, ocean acidification, extreme weather events, etc., caused by climate change, have major impacts on the environment, ecosystems of fragile marine and coastal areas. It pose a major threat to sustainable development of marine economy..

Accordingly, comprehensive analysis of the impact of climate change on various marine industries would provide the scientific basis for formulation of strategies and policies to combat climate change and promote development of marine economy, which would be of great practical significance. However, few articles on climate change have comprehensively discussed its overall impact on the marine economy. Previous research results have focused only on individual marine industries that are most sensitive to climate change, such as marine fisheries and coastal tourism.

\section{Impact of Climate Change on Marine Fisheries and Fishery Resources}

Many experts and scholars have investigated the impact of climate change on marine fishery resources, marine aquaculture and marine fishing. Nissling et al..$^{[4]}$ pointed out that climate change affects the salinity of the Baltic Sea, causing the fertilized eggs of Atlantic salmon to sink due to decreased sea water density, and die in an oxygen-deficient environment, so that the reproduction of the fish population is severely threatened. According to Grandcourt and $\mathrm{Cesar}^{[5]}$, the increase in seawater temperature has resulted in serious coral bleaching, which changed the habitat of coral reef fish, reduced its abundance, and even threated survival of the species. Roessing et al. ${ }^{[6]}$ analyzed the impact of climate change on physiology, natural environment, thus growth of tropical, temperate and frigid fishes, and the consequent impact on self-support, commercial, and recreational fisheries. The data shows that climate change has led to an increase in oxygen consumption by fish, which influences foraging and migratory behavior of fish in polar sea areas and bleached coral reefs, and predicts that significant changes in fish distribution can be caused by minimal changes in temperature. Another key aspect of climate change that impacts fisheries is seawater acidification. Hunt et al. ${ }^{[7]}$ pointed out that seawater acidification affects the calcification of plankton, and this effect will affect other populations through the food chain; Gazuau et al.$^{[8]}$ suggested that important economic species, such as oysters and mussels, will be the first to be affected as the $\mathrm{pH}$ and carbonate ion concentration decrease. In the latest report released by the IPCC ${ }^{[1]}$, using the SRES A1B scenario, the maximum catch for

*Corresponding author: ${ }^{a}$ yangwei@tio.org.cn 
1,000 species of fishes and invertebrates was estimated at a global scale. Taking China's coastal areas as example, the maximum potential catch in China's coastal areas would reduce to varying degrees in the $2050 \mathrm{~s}$, with an average reduction between $6 \%$ and $30 \%$, and more than $50 \%$ in some areas.

As to the impact of climate change on China's fishery resources and marine fisheries, domestic scholars have conducted some research. Liu Yunfen ${ }^{[9]}$ explored the possible impacts of rising sea temperatures on total amount and yield of major economic fish in the four major sea regions of China using the Fish Bioenergetics Model 2. The simulation results suggested that by 2030 , yield of the major economic fish species in the for major sea regions would decrease to varying degrees due to climate change - the total amount would decrease by $5 \%-15 \%$ and the yield by $1 \%-8 \%$. And the South China Sea area would be the most severely affected: the total amount would decrease by more than $10 \%$ and yield by nearly $10 \%$. Zhang Xuemin et al. ${ }^{[10]}$ conducted a preliminary study on the relationship between the sea surface temperature and the interannual variability of mackerel scad fish stock based on historical data. The results showed certain correlation between changes in sea surface temperature anomalies and mackerel scad fish stock index on the decadal scale. Since 1992, the proportion of temperate fish has dropped by $10-20 \%$, and the proportion of warm-water fish has increased, and the change postponed by 4 years after changes in water temperature. Wang Yuezhong et al. ${ }^{[1]}$ analyzed the changes in finfish catches in the northern South China Sea based on long-term serial fishery statistics and climate change data, and found that finfish catches in the northern South China Sea was not only related to fishing pressure, but also related to climate change. Global warming may cause an increase in rainfall in surrounding land areas in the future, and with increased input of terrestrial nutrients, the primary productivity of the ocean would be enhanced, which would contribute to the production of finfish fishery in the region. Chen Yunlong ${ }^{[12]}$ suggested that the increase of water temperature caused by climate change and the changes of environmental capacity will lead to a significant northward migration of squid resources in the middle and southern Yellow Sea, the center of these resources would move northward by up to $2.5-2.7^{\circ}$ in the next 30 years, $0.09^{\circ}$ per year on average.

\section{Impact of Climate Change on Coastal Tourism}

Coastal tourism is highly vulnerable to changes in the service functions of the ecosystem, such as coral reef bleaching, and frequent extreme weather events such as strong storm surges and extreme precipitation. With the rising sea level and sea surface temperature, and intensified coastal erosion and destruction of shoreline infrastructure by storm, the coastal tourism industry become more vulnerable ${ }^{[13]}$. Mclnnes et al. ${ }^{[14]}$ analyzed the negative impact of sea level rise and storm surge on seaside resorts in Queensland, Australia. Scott ${ }^{[15]}$ analyzed the impact of climate change on the temporal and spatial distribution of tourism climate resources in North America based on the Tourism Climate Index (TCI). The results showed that by the end of the $21 \mathrm{st}$ century, the tourism climate resources in North America will be extensively redistributed. More cities in the United States will become tourist destinations in the winter months, while traditional winter sunshine shores in Florida and Mexico will be negatively affected. Amelung et al. ${ }^{[16]}$ also analyzed the potential risks of climate change to the global tourism industry based on the TCI. The results show that climate change will lead to spatial and temporal redistribution of tourism resources: the ideal tourist climate conditions is expected to migrate to high-latitude areas, and the tourism seasons would also be affected, for example, the peak period of tourism in the Mediterranean region will shift from the summer months to the intermediate months. Amelung and Nicholls ${ }^{[17]}$ pointed out that climate change will lead to the migration of Australia's ideal tourism destination to the south, while the climate conditions in the northern tourism regions will be less attractive. In addition, there are a large number of studies focusing on Small Island Developing States (SIDS), which are extremely vulnerable to climate change. Attzs ${ }^{[18]}$, Nurse et al. ${ }^{[19]}$ investigated the impact of climate change on tourism industry of SIDSs: sea level rise, frequent occurrence of typhoon and other extreme disasters, the intensification of coastal erosion, and the outbreak of climate-sensitive diseases caused by climate change may all reduce the attractiveness of small islands as a preferred tourist destination.

As to the impact of climate change on domestic tourism, $\operatorname{Ren}^{[20]}$ analyzed the impact of climate changerelated key risks on China's tourism industry through simulations of China's future climatic conditions: an increase in winter temperature may lead to gradual shift of tourism destinations to the north; more rainfall in the north will accelerate erosion of local cultural landscapes such as ancient buildings in the summer; rising sea level, frequent storm surges, and accelerated shoreline erosion will destroy coastal roads, hotels and other tourist facilities. Ma Li and Fang Xiuqi ${ }^{[21]}$ discussed the impact of climate warming on the seasonal tourism of the Peach Blossom Festival in Beijing Botanical Garden based on historical data analysis. The results showed that the average start date of Peach Blossom Festival after 1994 was about 6 days earlier than that in the earlier years; in general, climate warming would make the Peach Blossom Festival last longer, but climate fluctuations lead to uncertainty in seasonal tourism products, which is detrimental to this industry and the associated socioeconomic interests. $\mathrm{Xi}$ Jianchao et al. ${ }^{[22]}$ used the climate-tourism flow model to simulate and predict the impact of climate change on the tourism flows in the five southern provinces of Zhejiang, Guangdong, Hainan, Sichuan, and Yunnan. The results suggested that the winter tourism flows in all these regions would generally grow, with Guangdong as the leading province; while in summer, tourism flow in all these regions would decrease, especially in Guangdong and Hainan. Tang et al. ${ }^{[23]}$ established an evaluation system to analyze the 
impact of climate change on tourism in Xiamen, and clarified the extent to which Xiamen's tourism development would be affected by climate change. Liu Shaojun et al. ${ }^{[24]}$ discussed the decline in climate comfort and decrease in number of tourists in certain months (April, July, and October) in Hainan caused by climate change basing on the tourism-climate index model.

\section{Impact of Climate Change on Other Major Marine Industries}

The negative impact of climate change on the marine transportation industry is mainly reflected in two aspects: the loss caused by climate disasters and the pressure of emission reduction policies on the shipping industry. In terms of losses caused by climate disasters: sea level rise will decrease the relative height of port terminals and warehouses, resulting in increased risk of storm surge floods and impaired port function ${ }^{[25]}$; extreme weather events will lead to breaks in harbor operations and transportation, damage to facilities, and staff casualties $^{[13]}$. In addition, the low-carbon shipping model promoted for climate change mitigation ${ }^{[26,27]}$ has a more significant impact on the shipping industry: the ship, power, route, and management systems all need to be improved $^{[28]}$.

Climate change also has a potential impact on the exploitation and utilization of marine resources, and the offshore oil and gas platforms are particularly vulnerable ${ }^{[13]}$. On the other hand, actions to mitigate climate change will promote the development of ocean energy industry ${ }^{[29,30]}$, which seeks to achieve carbon reduction goals by increasing the contribution of ocean energy to national energy structure.

\section{Identification of the key impacts of climate change on marine economy}

The impacts of climate change are driven by the following 5 aspects: sea level rise, sea surface temperature rise, acidification of seawater, extreme weather, and emission reduction policies. Basing on review of the above studies on the impact of climate change on marine economy and expert consultations, this section summarizes the impact of the different drivers on marine industries (Table 1). According to the statistics of the "Statistical Bulletin of China's Marine Economy", analysis of the impact on the marine economy in this study included 12 major marine industries, which are marine fisheries, offshore oil and gas industry, marine salt industry, marine biological medicine, marine mining, and oceanography, marine transportation industry, marine chemical industry, ocean construction industry, ocean power industry, marine shipbuilding industry, seawater utilization industry, and coastal tourism. And the specific interpretations and definitions of different marine industries are based on the contents of Appendix 2 of the "Statistical Bulletin of China's Marine Economy".

\section{Summary and Suggestions}

Current studies suggest that climate change has a remarkable impact on marine economy, and some marine industries are especially vulnerable. There are both negative and positive consequences of climate change. Negatively, rise in sea surface temperature will lead to decreased fishery resources, seawater acidification will affect the growth of crustaceans, sea level rise will inundate coastal tourism facilities and port facilities, extreme weather conditions will affect coastal tourism, disrupt port operations, interfere oil and gas platforms, etc. Positively, high-latitude regions will attract more tourists, and implementing carbon reduction policies can promote the development of the ocean energy industry.

On the whole, however, negative and unfavorable effects dominate. The government should take pertinent measures to mitigate the adverse effects of climate change.

1) Implement effective countermeasures. Enhance research on climate change monitoring and forecasting, and establish a technology support system to adapt to climate change. Strengthen the construction of coastal moisture-proof facilities and improve the design standards of damp-proof facilities to cope with the impact of extreme sea-level rise scenarios. Strengthen the monitoring and early warning capabilities for typhoons and storm surges. Optimize distribution of marine industries and focuses of industrial development, including: developing high-latitude ocean fishery industry; strengthening prevention of marine aquaculture, especially mudflat aquaculture; optimizing the distribution of port terminals and coastal tourism facilities to enhance their adaptability to sea level rise; and encouraging development of marine industries with high added value, such as marine chemicals, marine biological medicine, and ocean power, which are less affected by climate change.

2) Conduct active mitigation actions. Formulate reasonable emission reduction targets and paths, taking socio-economic welfare into account. Optimize the marine industrial structure and develop green and lowcarbon marine industries. On one hand, it is necessary to transform and upgrade the growth mode of traditional marine economy. For example, by improving the energy efficiency and changing energy structure of high-energyconsuming oceanic sectors, such as marine mining and salt industry, ocean chemical industry, marine ship manufacturing industry, and marine transportation industry, it will not only achieve the goal of reducing carbon emissions, but also reduce the adverse effects of carbon tax policy implementation on these industries. On the other hand, we should vigorously promote the development of marine energy industry, which would play an important role in changing the energy structure and realizing the development of a low-carbon economy. 
Table 1. Key Impacts of Climate Change and Emission Reduction Policies on Marine Industries.

\begin{tabular}{|c|c|c|c|c|c|}
\hline & Sea-level rise & $\begin{array}{c}\text { Sea surface } \\
\text { temperature rise }\end{array}$ & $\begin{array}{c}\text { Seawater } \\
\text { acidification }\end{array}$ & Extreme weather & $\begin{array}{l}\text { Emission reduction } \\
\text { policy }\end{array}$ \\
\hline $\begin{array}{l}\text { Marine } \\
\text { fishery }\end{array}$ & $\begin{array}{l}\text { 1. Inundation of } \\
\text { beach culture areas; } \\
2 . \text { Inundation of } \\
\text { factory buildings } \\
\text { which affects } \\
\text { aquatic product } \\
\text { processing. }\end{array}$ & $\begin{array}{l}\text { 1. Change the } \\
\text { habitat environment, } \\
\text { and reduce fish } \\
\text { population; } \\
\text { 2. Change the } \\
\text { spatial distribution } \\
\text { of fishery resources. }\end{array}$ & $\begin{array}{l}\text { 1. Influence the life } \\
\text { history of fish, } \\
\text { change the habitat } \\
\text { environment, reduce } \\
\text { fish population, and } \\
\text { affect marine } \\
\text { fishing. }\end{array}$ & $\begin{array}{l}\text { 1. Damage } \\
\text { aquaculture facilities; } \\
\text { 2. Affect the normal } \\
\text { development of } \\
\text { outdoor farming and } \\
\text { fishing activities. }\end{array}$ & $\begin{array}{l}\text { 1. Energy } \\
\text { conservation and } \\
\text { emission reduction } \\
\text { affect marine } \\
\text { fishing. }\end{array}$ \\
\hline $\begin{array}{l}\text { Marine oil } \\
\text { and gas } \\
\text { industry }\end{array}$ & $\begin{array}{l}\text { 1. Increase the } \\
\text { difficulty and cost } \\
\text { of mining. }\end{array}$ & & & $\begin{array}{l}\text { 1. Affect exploration, } \\
\text { transportation and } \\
\text { other production } \\
\text { activities. }\end{array}$ & $\begin{array}{l}\text { 1. Change the } \\
\text { energy structure } \\
\text { and reduce the } \\
\text { need for fossil } \\
\text { fuels. }\end{array}$ \\
\hline $\begin{array}{l}\text { Ocean } \\
\text { mining }\end{array}$ & $\begin{array}{l}\text { 1. Increase the } \\
\text { difficulty and cost } \\
\text { of mining. }\end{array}$ & & & $\begin{array}{l}\text { 1. Affect coastal ore } \\
\text { and other mining } \\
\text { activities. }\end{array}$ & $\begin{array}{l}\text { 1. Change the } \\
\text { energy structure } \\
\text { and reduce the } \\
\text { demand for coal. }\end{array}$ \\
\hline $\begin{array}{l}\text { Ocean salt } \\
\text { industry }\end{array}$ & $\begin{array}{l}\text { 1. Inundation of } \\
\text { existing salt pan; } \\
\text { 2. Inundation of the } \\
\text { factory buildings } \\
\text { and affect salt } \\
\text { processing. }\end{array}$ & & & $\begin{array}{l}\text { 1. Storm surge } \\
\text { damages salt fields; } \\
\text { 2. Affect outdoor salt } \\
\text { mining activities. }\end{array}$ & $\begin{array}{l}\text { 1. Change the } \\
\text { existing production } \\
\text { mode. }\end{array}$ \\
\hline $\begin{array}{l}\text { Marine } \\
\text { chemical } \\
\text { industry }\end{array}$ & $\begin{array}{l}\text { 1. Inundation of the } \\
\text { factory and affect } \\
\text { normal production } \\
\text { activities. }\end{array}$ & & & $\begin{array}{l}\text { 1. Reduce number of } \\
\text { days for normal } \\
\text { production activity. } \\
\text { However, the impact } \\
\text { on indoor production } \\
\text { is relatively low. }\end{array}$ & $\begin{array}{l}\text { 1. Change the } \\
\text { existing production } \\
\text { mode. }\end{array}$ \\
\hline $\begin{array}{l}\text { Marine } \\
\text { biomedici } \\
\text { ne }\end{array}$ & $\begin{array}{l}\text { 1. Inundation of the } \\
\text { factory and affect } \\
\text { normal production } \\
\text { activities. }\end{array}$ & & & $\begin{array}{l}\text { 1. Reduce number of } \\
\text { days for normal } \\
\text { production activity. } \\
\text { However, the impact } \\
\text { on indoor production } \\
\text { is relatively low. }\end{array}$ & $\begin{array}{l}\text { 1. Change the } \\
\text { existing production } \\
\text { mode. }\end{array}$ \\
\hline $\begin{array}{l}\text { Marine } \\
\text { power } \\
\text { industry }\end{array}$ & $\begin{array}{l}\text { 1. Increase the } \\
\text { construction cost; } \\
2 \text {. Some wind } \\
\text { turbines would be } \\
\text { flooded and } \\
\text { additional protection } \\
\text { is needed. }\end{array}$ & & & $\begin{array}{l}\text { 1. Storm surge } \\
\text { increases the number } \\
\text { of off days for the } \\
\text { turbines; } \\
\text { 2. Storm surge } \\
\text { increases the } \\
\text { construction cost of } \\
\text { tidal and wave power } \\
\text { station. }\end{array}$ & $\begin{array}{l}\text { 1. Change the } \\
\text { energy structure } \\
\text { and increase the } \\
\text { demand for clean } \\
\text { energy such as } \\
\text { offshore wind } \\
\text { energy and ocean } \\
\text { energy. }\end{array}$ \\
\hline $\begin{array}{l}\text { Seawater } \\
\text { utilization } \\
\text { industry }\end{array}$ & $\begin{array}{l}\text { 1. Inundation of the } \\
\text { factory and affect } \\
\text { normal production } \\
\text { activities. }\end{array}$ & & & $\begin{array}{l}\text { 1. Reduce number of } \\
\text { days for normal } \\
\text { production activity. } \\
\text { However, the impact } \\
\text { on indoor production } \\
\text { is relatively low. }\end{array}$ & $\begin{array}{l}\text { 1. Change the } \\
\text { existing production } \\
\text { mode. }\end{array}$ \\
\hline $\begin{array}{l}\text { Marine } \\
\text { ship } \\
\text { building } \\
\text { industry }\end{array}$ & $\begin{array}{l}\text { 1. Inundation of } \\
\text { docks and factories; } \\
\text { 2. Heightening of } \\
\text { the port would } \\
\text { increase production } \\
\text { costs. }\end{array}$ & & & $\begin{array}{l}\text { 1. Affect outdoor } \\
\text { ship repair and } \\
\text { dismantling; } \\
\text { 2. Increase cost for } \\
\text { protection against } \\
\text { storm surges. }\end{array}$ & $\begin{array}{l}\text { 1. Change the } \\
\text { existing production } \\
\text { mode. }\end{array}$ \\
\hline $\begin{array}{l}\text { Marine } \\
\text { engineerin } \\
\mathrm{g} \\
\text { constructi } \\
\text { on }\end{array}$ & $\begin{array}{l}\text { 1. The demand for } \\
\text { construction of } \\
\text { protective } \\
\text { infrastructures rises; } \\
\text { 2. Increase } \\
\text { construction costs; } \\
\text { 3. Inundation of } \\
\text { existing production } \\
\text { facilities. }\end{array}$ & & & $\begin{array}{l}\text { 1. Promote the } \\
\text { development of } \\
\text { marine engineering } \\
\text { construction; } \\
\text { 2. Reduce the } \\
\text { number of days for } \\
\text { normal outdoor } \\
\text { construction work. }\end{array}$ & $\begin{array}{l}\text { 1. Change the } \\
\text { existing production } \\
\text { mode. }\end{array}$ \\
\hline
\end{tabular}




\begin{tabular}{|c|c|c|c|c|c|}
\hline $\begin{array}{l}\text { Marine } \\
\text { transportat } \\
\text { ion } \\
\text { industry }\end{array}$ & $\begin{array}{l}\text { 1. Inundation of port } \\
\text { terminals affect } \\
\text { normal production } \\
\text { activities; } \\
\text { 2. Increase } \\
\text { production costs. }\end{array}$ & & & $\begin{array}{l}\text { 1. The storm surge } \\
\text { affects the number of } \\
\text { days for normal sea } \\
\text { transportation; } \\
\text { 2. Affect outdoor } \\
\text { activities; } \\
\text { 3. Increase cost for } \\
\text { protection against } \\
\text { storm surges. }\end{array}$ & $\begin{array}{l}\text { 1. low-carbon } \\
\text { shipping mode. }\end{array}$ \\
\hline $\begin{array}{l}\text { Coastal } \\
\text { tourism }\end{array}$ & $\begin{array}{l}\text { 1. Inundation of } \\
\text { coastal tourism } \\
\text { resources, including } \\
\text { cultural relics and } \\
\text { natural landscapes } \\
\text { such as wetlnds; } \\
\text { 2. Inundation of } \\
\text { coastal holiday } \\
\text { accommodation. }\end{array}$ & $\begin{array}{l}\text { 1. Loss of natural } \\
\text { landscape of the sea; } \\
\text { 2. Change the } \\
\text { spatial distribution } \\
\text { of tourism } \\
\text { resources. }\end{array}$ & $\begin{array}{l}\text { 1. The marine } \\
\text { ecosystem would be } \\
\text { damaged and the } \\
\text { natural landscape } \\
\text { would be lost. }\end{array}$ & $\begin{array}{l}\text { 1. Destroy the } \\
\text { cultural relics of the } \\
\text { coastal zone and } \\
\text { natural landscapes } \\
\text { such as wetlands; } \\
\text { 2. Reduce ocean } \\
\text { sightseeing and other } \\
\text { outdoor leisure } \\
\text { activities. }\end{array}$ & $\begin{array}{l}\text { 1. Change the } \\
\text { existing production } \\
\text { mode. }\end{array}$ \\
\hline
\end{tabular}

\section{Acknowledgements}

Project supported by Fujian Province Foundation for Public Welfare Scientific Research Institution (2017R1006-6).

\section{References}

1. IPCC. Climate Change 2014: Synthesis Report, Summary for Policymakers (2014).

2. Wang N, ZhangL Q, Yuan L, et al. Acta Ecologica Sinica, 32(7): 2248-2258 (2012).

3. IPCC. Climate Change 2013: The Physical Science Basis. Summary for Policymakers (2013).

4. Nissling A, Larsson R, Vallin L, et al. Fisheries Research, 38(2): 169-186 (1998).

5. Grandcourt E M, Cesar H S J. Fisheries Research, 60(2-3): 539-550 (2003).

6. Roessing $\mathrm{J}$ M, Woodley $\mathrm{C}$ M, Cech $\mathrm{J} \mathrm{J}$, et al. Reviews in Fish Biology and Fisheries, 14: 251-275 (2004).

7. Hunt B P V, Pakhomov E A, Hosie G W, et al. Progress in Oceanography, 78(3): 193-221 (2008).

8. Gazeau F, et al. Geophysical Research Letters, 34(7), L07603, doi: 10.1029/2006GL028554 (2007).

9. Liu Yunfen. Chinese Journal of Agrometeorology, 21(4): 1-5 (2000).

10. Zhang Xuemin, Shang Shaoping, Zhang Caiyun, et al. Marine Science Bulletin, 24(4): 91-96 (2005).

11. Wang Y Z, Sun D R, Chen Z Z, et al. Acta Ecologica Sinica, 32(24): 7948-7957 (2012).

12. Chen Yunlong. Degree paper of Ocean University of China (2014).

13. Cai Rongshuo, Qi Qinghua. Advances in Climate Change Research, 10(3): 185-190 (2014).

14. Mclnnes K L, Walsh K J E, Pittock A B. A Report for CSIRO Tourism Research (2000).

15. Scott D, McBoyle G, Schwartzentruber M. Climate Research, 27: 105-117 (2004).
16. Amelung B, Nicholls S, Viner D. Journal of Travel Research, 45: 285-296 (2007).

17. Amelung B, Nicholls S. Tourism Management, 41: 228-244 (2014).

18. Attzs M. Worldwide Hospitality and Tourism Themes, 1(3): 231-251 (2009).

19. Nurse K, Niles K, Dookie D. NCRR Swiss Climate Research Conference on the International Dimensions of Climate Policies, 21-23 (January 2009).

20. Ren G Y. The Journal of Chinese Geography, 6(2): 97-102 (1996).

21. Ma Li, FANG Xiu-qi. Advances in Earth Science, 21(3): 313-319 (2006).

22. Xi Jianchao, ZHAO Meifeng, GE Quansheng. Tourism Tribune, 26(11): 78-63 (2011).

23. Tang Decai, Wang Linjia, Li Changshun, et al. Advances in Climate Change Research, 10(5): 370375 (2014).

24. Liu Shaojun, ZHANG Jinghong, WU Shengan, et al. Journal of Tropical Meteorology, 30(5): 977-982 (2014).

25. Division of Earth Science, Chinese Academy of Sciences. The impact of sea level rise on China's delta region and the countermeasures (Science Press, 1994).

26. Haites E. Climate Policy, 9(4): 415-430 (2009).

27. Sun Jiaqing. Marine Technology, (6): 73-75 (2013).

28. Liu Xiancheng. Degree paper of Dalian Maritime University (2012).

29. Zhao Shiming, Liu Fuyou, Zhang Junhai, et al. Journal of Ocean Technology, 27(3): 80-83 (2008).

30. Allan G J, Lecca P, McGregor P G, et al. Marine Policy, 43: 122-131 (2014). 